CZASOPISMO INŻYNIERII LĄDOWEJ, ŚRODOWISKA I ARCHITEKTURY JOURNAL OF CIVIL ENGINEERING, ENVIRONMENT AND ARCHITECTURE JCEEA, t. XXXIV, z. 64 (3/II/17), lipiec-wrzesień 2017, s. 371-382, DOI:10.7862/rb.2017.179

Marcin TUR ${ }^{1}$

\title{
ANALIZA BILANSU ENERGETYCZNEGO ZABYTKOWEJ ZABUDOWY DZIELNICY BOJARY W BIAEYMSTOKU, JAKO ELEMENT PROGRAMU REWITALIZACJI
}

\begin{abstract}
Dostosowanie historycznych budynków do współczesnych wymagań w zakresie komfortu cieplnego przy jednoczesnym utrzymaniu niskich kosztów eksploatacji jest jednym głównych przeszkód w procesie rewitalizacji zabytkowych dzielnic. Brak ujęcia w programie rewitalizacji analiz efektywności usprawnień termomodernizacyjnych uwzględniających kompromis pomiędzy wymaganiami konserwatorskimi, a analizą energetyczną i ekonomiczną, może prowadzić do fiaska programu rewitalizacji i zniszczenia zabytkowej substancji historycznej. Śródmiejska dzielnica Białegostoku - Bojary jest przykładem zanikającego na naszych oczach materialnego i kulturowego dziedzictwa miasta. Na jej terenie znajduje się jednolita stylowo drewniana zabudowa, która wartość zabytkową zachowuje nie tylko w warstwie wizualnej, ale także w postaci wyjątkowych ówcześnie rozwiązań gospodarowania ciepłem. W okresie kilkudziesięciu ostatnich lat, dzielnica doświadczała wielu działań modernizacyjnych - od nieskrępowanego przepisami ożywienia inwestycyjnego lat 90. XX w., po wprowadzenie rygorystycznego wzornika zabudowy. Artykuł przedstawia rys historyczny dzielnicy jako uzasadnienie potrzeby jej ochrony, obecny stan zachowania i podejmowane dotychczas działania modernizacyjne. Opisana została analiza bilansu energetycznego domów bojarskich, z uwzględnieniem wyników przeprowadzonych badań szczelności powietrznej. Opracowanie zostało oparte na podstawie badań terenowych, inwentaryzacji oraz metod obliczeniowych obejmujących bilans energetyczny i wpływ szczelności powietrznej. Wynikiem badań jest przedstawienie efektywności energetycznej jako jednego z kluczowych aspektów rewitalizacji.
\end{abstract}

Słowa kluczowe: Domy drewniane, konserwacja zabytków, efektywność energetyczna, szczelność powietrzna

\footnotetext{
${ }^{1}$ Marcin Tur, Politechnika Białostocka, Wydział Architektury, ul. Oskara Sosnowskiego 11, 15-893 Białystok; tel.: 510712 071; e-mail: marcin-tur@wp.pl

(badania zostały zrealizowane w ramach pracy nr S/WA/1/2016 i sfinansowane ze środków na naukę MNiSW)
} 


\section{Wartość historyczna dzielnicy}

Białostocka dzielnica Bojary, położona w centrum 300-tysięcznego miasta, swoją drewnianą zabudową stanowi świadectwo historii miasta. ratowania jej krajobrazu i drewnianej zabudowy, rozpoczęły się blisko 40 lat temu i podejmowane były przez wszystkie kompetentne instytucje jak również mieszkańców dzielnicy. Efekty tych działań nie są jednoznaczne. Jedną z przyczyn może być brak ujęcia $w$ programach naprawczych problemu dostosowania wiekowych konstrukcji do współczesnych wymagań użytkowych i pozostawienie wolnej ręki inwestorom w kwestii rozwiązań technicznych. Nie podejmowano również próby zmiany stereotypowej opinii o niskiej wartości materialnej i użytkowej domów drewnianych. Przeprowadzone badania bilansu energetycznego i szczelności powietrznej identyfikują obszary problemowe odpowiedzialne za taką opinię. Dostępne współcześnie technologie pozwalają na uzyskanie efektywnego kompromisu między wymaganiami użytkowymi i ochrony konserwatorskiej. W zbyt wielu przypadkach podcięcie decyzji o rozbiórce, czy zniszczeniu drewnianego domu, przebiegało automatycznie - w debacie publicznej w Białymsto$\mathrm{ku}$ powszechne jest pejoratywne określanie stuletniej drewnianej zabudowy ścisłego centrum miasta. Tymczasem to właśnie taka zabudowa jest jednym $\mathrm{z}$ trzech filarów tożsamości miasta, na równi z organizującym miasto założeniem pałacowym i zabudową przemysłową z czasów XIX-wiecznej rewolucji włókienniczej.

Historia Bojar jest być może równie stara jak Białegostoku, analiza linii podziału parcel może prowadzić do stwierdzenia istnienia $\mathrm{w}$ miejscu dzielnicy wsi przed 1547 r. $^{2}$ Nazwa związana jest kategorią zamieszkującej wieś ludności - bojarów (putnych), zobowiązanych do służenia na dworze jako posłańcy ${ }^{3}$. Na datowanym na 1774 r. planie-projekcie miasta osada posłańców (Village desMessagers) pojawia się przy dzisiejszej ulicy Warszawskiej będącą zachodnią granicą dzielnicy ${ }^{4}$, w XIX w. zwaną ulicą Bojarską. W XIX w. Białystok przeżył gwałtowny rozwój za sprawą przenoszenia z terenów Królestwa Polskiego przemysłu włókienniczego. „W latach 1860-1910 liczba mieszkańców powiększyła się czterokrotnie do około 82,5 tys. osób", wokół powstających fabryk rozwijały się osiedla drewnianych domów. Dzielnica w częściowo zachowanym do dziś kształcie uformowała się w ostatniej dekadzie XIX w. Wernakularna zabudowa Bojar była wynikiem kilku wieków ewolucji drewnianego domu, a także mieszania się wpływów wielu zamieszkujących Białystok kultur.

\footnotetext{
${ }^{2}$ Popławski T.: Przestrzeń współczesnego miasta Białegostoku na tle historycznych podziałów, Białostocczyzna 2/96, Białystok 1996 r., s. 11-12.

${ }^{3}$ Korolczuk D., Maroszek J., Popławski T.: Wartości przestrzeni i środowiska kulturowego dzielnicy Bojary, Białostocczyzna 3/94, Białystok 1994 r., s. 72.

4 Turecki A.: „Plan duChateau et de la ville de Białystok avecsesenvirons”, Zeszyty Naukowe Politechniki Białostockiej 1996 r.

${ }^{5}$ Dobroński A.: Białystok, historia miasta, Urząd Miasta Białegostoku, Białystok 2001.
} 
Drewniane domy aż do czasów budownictwa uprzemysłowionego lat 50. XX w. dominowały w zabudowie mieszkaniowej miasta - w 1879 r. na 2180 domów mieszkalnych, tylko 45 było murowanych. W 1890 r. zanotowano 3789 domów drewnianych i 576 murowanych. ${ }^{6} \mathrm{~W}$ dwudziestoleciu międzywojennym pojawiła się modernistyczna wersja drewnianego domu w konstrukcji wieńcowej, wyposażona w przestronne, funkcjonalne wnętrza i duże okna ${ }^{7}$ (istniejące na Bojarach trzy obiekty). Czasy PRL przyniosły wraz z rozbudową miasta i upowszechnianiem budownictwa wielkoprzemysłowego zdecydowaną zmianę, skutkującą sukcesywną degradacją zabudowy drewnianej. Wynikało to w dużej mierze z przekształceń własnościowych po wojnie - duża liczba domów stała się własnością miasta i stanowiły bazę komunalnych lokali mieszkalnych. To legło u podstaw problemów społecznych „,drewnianych” dzielnic miasta. Ówczesna polityka przestrzenna zakładała zaniechanie modernizacji dzielnic z przeznaczeniem terenów na budownictwo uprzemysłowione (rys. 1.) [1-7].

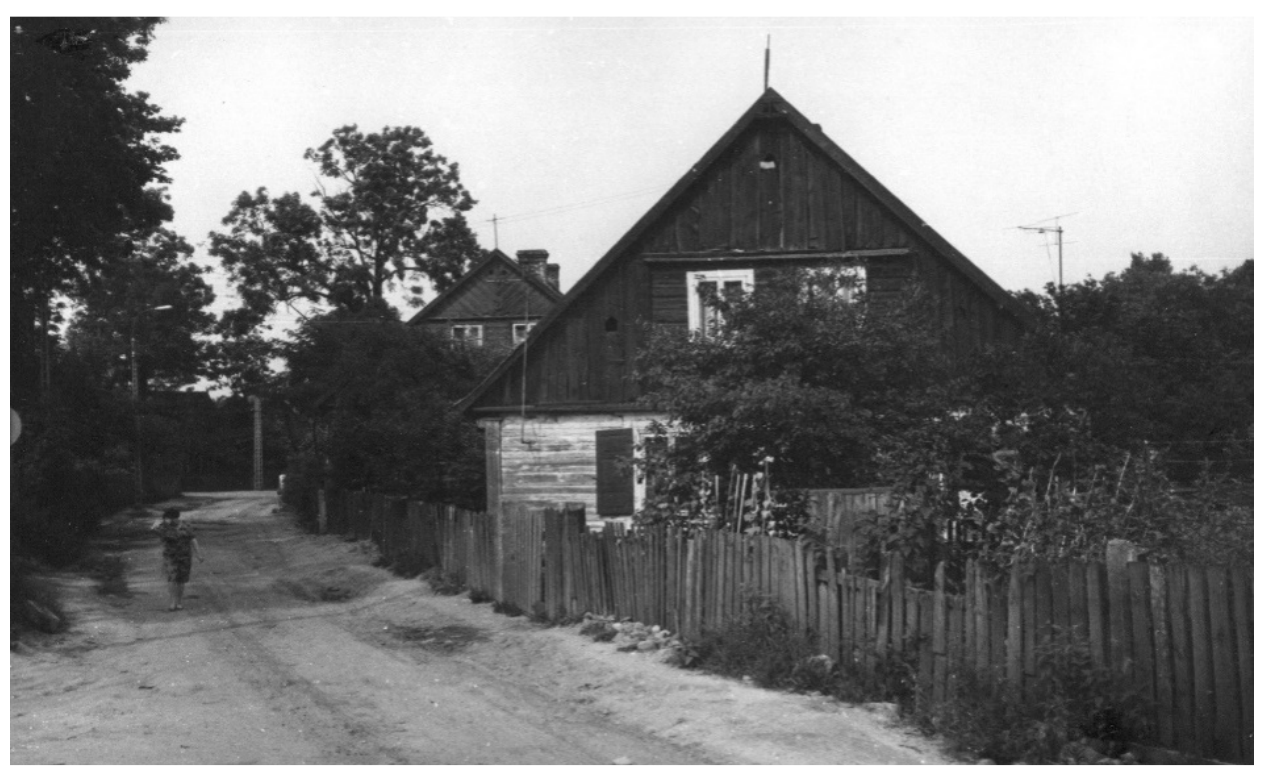

Rys. 1. Bojary na początku lat 80. XX w. (PP PKZ O/Białystok, NID w Białymstoku) ${ }^{8}$

Fig. 1. Bojary district in the early 1980s. (PP PKZ O/Białystok, archives of the National Heritage Board of Poland)7

\footnotetext{
${ }^{6}$ Dolistowska M.: W poszukiwaniu..., s. 151-155.

7 Wicher S.: ,Drewniany” modernizm w Białymstoku na przykładzie domu przy ul. Słonimskiej 31, Biuletyn Konserwatorski Województwa Podlaskiego, Białystok 2008.

${ }^{8}$ Dokumentacja fotograficzna dzielnicy Bojary, P.P. P.K.Z./O Białystok, lata 80. XX w. archiwum Narodowego Instytutu Dziedzictwa OT w Białymstoku.
} 
Popularność budownictwa drewnianego wynikała z zarówno niskich kosztów i szybkości budowy, jak i doskonałych ówcześnie parametrów cieplnych. Wypracowany na przełomie XIX i XX w. wernakularny „standard” budowy białostockich domów zapewniał osiągnięcie najlepszych parametrów komfortu cieplnego w porównaniu do innych ówcześnie dostępnych typów konstrukcji, w tym budynków murowanych ${ }^{9}$. Poprawie komfortu cieplnego służyły: precyzyjnie wykonana warstwa szalówki; wyposażenie okien skrzynkowych w przylegające okiennice; układ przestrzenny pomieszczeń; konstrukcja osłony termicznej oraz skomplikowane, ale niezwykle funkcjonalne podlaskie systemy piecowe ${ }^{10}$. Nie należy także traktować domów drewnianych jako nietrwałych dobre osłonięta szalówką konstrukcja wieńcowa umożliwiała wymianę uszkodzonych przez brak bieżącej konserwacji elementów budynku - w tym, typowy zabieg - wymianę podwalin. Powyższe techniki w połączeniu z kształtem bryły stanowiły standard wykorzystywany do II poł. XX w na terenie całej Białostocczyzny.. Ten dorobek techniczny można traktować zgodnie z myślą Jana Zachwatowicza jako część dziedzictwa kulturowego na równi z formą i dekoracją budynku. Dzielnica do połowy lat 90 . XX wieku zachowała się niemal w oryginalnym stanie (w cudowny sposób uchodząc cało z pożogi wojennej, w której ucierpiało $80 \%$ zabudowy centrum), kiedy rozpoczęła się nieskrępowana i chaotyczna gorączka inwestycyjna prowadząca do nieodwracalnej utraty autentyzmu krajobrazu dzielnicy (rys. 2.) [8-9].

\section{Działania ochronne i przekształcenia}

Pierwszym dokumentem zmieniającym spojrzenie planistów na budynki drewniane było studium historyczno-urbanistyczne do MPZP miasta, napisane w 1978 r. przez Antoniego Oleksickiego, wskazujące na wartość zabytkową dzielnicy Bojary. Powstały w 1985 r. MPZP ignorował zalecenia studium i prowadził przez Serce Bojar arterię komunikacyjną ${ }^{11}$. W 1988 r. podpisano „Kartę Bojarską", dokument utworzony przez IX Ogólnopolskie Sympozjum Architektury Regionalnej PAN, uznający Bojary za unikatowy w skali kraju zespół urbanistyczny architektury regionalnej. Postulowano w niej rozszerzenie strefy konserwatorskiej i opracowanie programu rewitalizacji dzielnicy. Uchwalony w 1993 r. MPZP jak i ogólna polityka miasta uwzględniały w dużej mierze postulaty „Karty” m.in. wprowadzając strefy ochrony konserwatorskiej i krajobra-

\footnotetext{
9 Tur M.: Sposoby kształtowania komfortu cieplnego w drewnianym budownictwie mieszkaniowym Białegostoku z początku XX w., Wybrane kierunki badań ergonomicznych w 2016 r., Wydawnictwo Polskiego Towarzystwa Ergonomicznego, Wrocław 2016.

${ }^{10}$ Szewczyk J.: Piec i komin w tradycyjnym budownictwie ludowym Podlasia, Oficyna Wydawnicza Politechniki Białostockiej, 2011 r.

11 Dąbrowska-Milewska G.: Problemy ochrony wartości kulturowych w praktyce planowania przestrzennego na przykładzie dzielnicy Bojary w Białymstoku, Zeszyty naukowe Politechniki Białostockiej $1996 \mathrm{r}$.
} 
zu. Opracowana w 1997 r. strategia rozwoju Białegostoku porusza problem Bojar, określając tereny dzielnicy jako „bardzo atrakcyjnej lokalizacji”, oraz „przewidziany do rewaloryzacji terenów w obszarze ochrony konserwatorskiej”12. W 2006 r. dzięki inicjatywie stowarzyszenia mieszkańców i miłośników dzielnicy „Nasze Bojary” podjęta została dyskusja publiczna o utworzeniu parku kulturowego, jako skutecznej formie ochrony Bojar. Władze miasta w odpowiedzi na tą inicjatywę rozpoczęły prace nad nowym MPZP zlecając opracowanie konserwatorsko-urbanistyczne, które wskazywało na nieskuteczność dotychczasowych form ochrony w postaci wpisu terenu dzielnicy do rejestru oraz powierzchownych zapisów w MPZP, podważało zasadność tworzenia parku kulturowego ze względu na ,istniejącą dysharmonią spowodowaną wprowadzeniem dużej ilości nowej zabudowy"13 prowadzącą do braku autentyzmu. Opracowanie wskazywało możliwość uzyskania skutecznej ochrony odpowiednimi narzędziami planistycznymi. Uchwalony w 2007 r. MPZP wraz załącznikiem w postaci pierwszego w województwie podlaskim wzornika zabudowy, określał gabaryty, kąty nachylenia dachów, wykończenie zewnętrzne, umiejscowienie otworów okiennych i lukarn, a także lokalizację nowych budynków na pustych działkach i przebudowy istniejących. Plan wprowadzał nakaz odbudowy budynków w ich pierwotnej formie przypadku pożaru [10-12].

W 2010 r. opracowany został Lokalny Program Rewitalizacji Miasta Białegostoku, w którym nakreślono kierunki działań w dzielnicy Bojary. Priorytetem pozostała „ochrona charakteru architektonicznego i urbanistycznego”, wskazano również na potrzebę ,stworzenia w dzielnicy przestrzeni publicznych do rozwoju funkcji turystycznych i kulturalnych (galeria, małe muzea) oraz wypoczynkowo-rekreacyjnych (gastronomia), w tym utworzenie ścieżek edukacyjnych ukazujących wartości historyczne bojarskich domów". Po siedmiu latach od utworzenia LPR, w obszarze Serca Bojar funkcjonują: jedno małe muzeum (bud. Przy ul. Wiktorii 5), dwa lokale gastronomiczne, społeczny Bojarski Dom Kultury organizujący imprezy plenerowe, oznakowany został szlak architektury drewnianej. Co znamienne, jedna z tabliczek z informacją o domu przy ul. Chopina 3, stoi dziś na pustej działce. Program zwracał uwagę na problem zanieczyszczenia powietrza wynikający z braku uzbrojenia terenu w media energetyczne i ogrzewanie domów piecami na paliwo stałe. Dziś na badanym terenie funkcjonuje sieć gazu ziemnego.

\footnotetext{
${ }^{12}$ Polityka mieszkaniowa Białegostoku”, UM w Białymstoku, Białystok, $1997 \mathrm{r}$.

13 Oleksicki A., Tomecka B., Stanisławska A., Lewkowicz P.: Opracowanie konserwatroskourbanistyczne dla dzielnicy Bojary wykonane na zlecenie Prezydenta Miasta Białegostoku, PPKZ S.A. O/Białystok, 2006.
} 


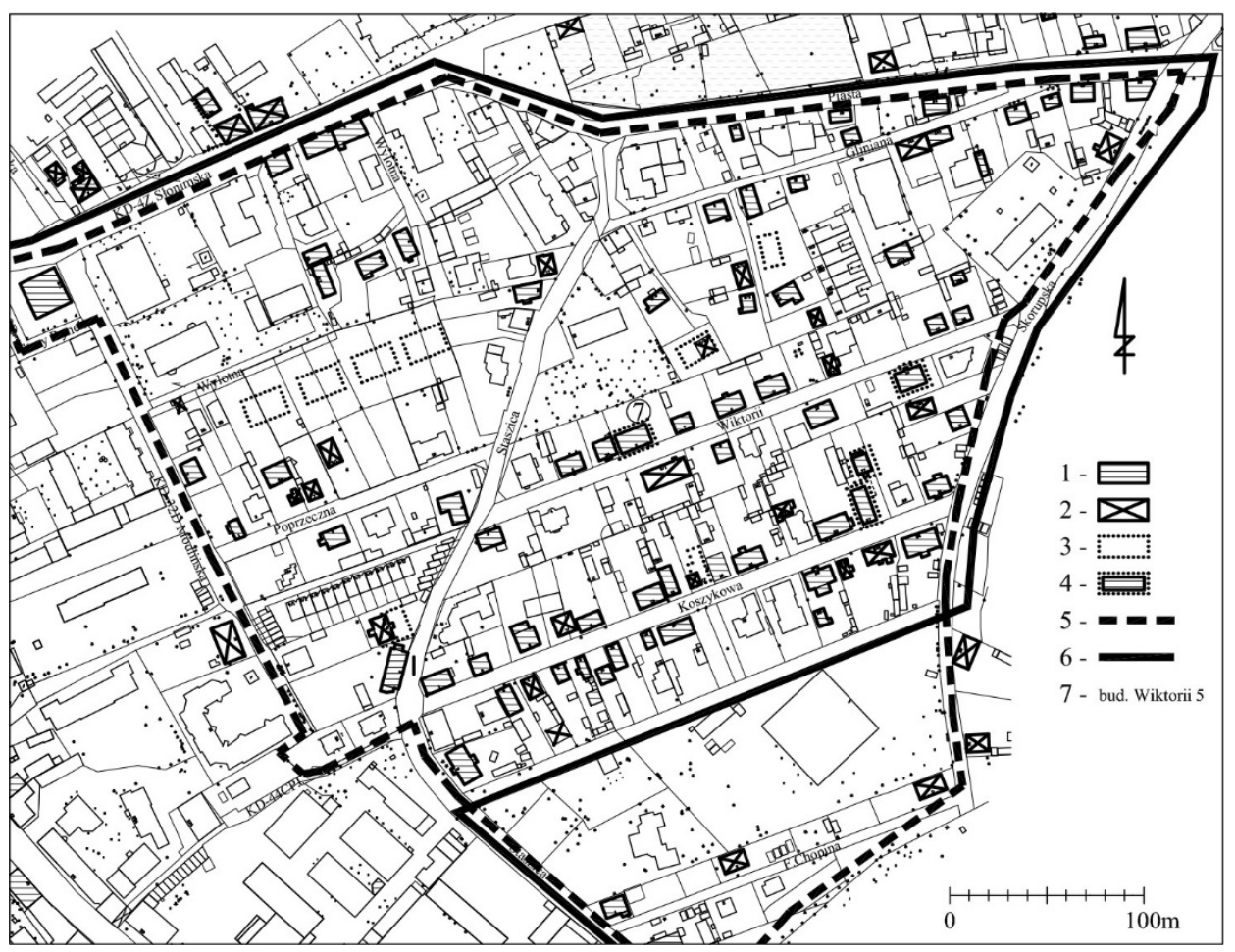

Rys. 2. Zabudowa drewniana głównej części dzielnicy Bojary. Oznaczenia: 1. - Domy drewniane istniejące; 2. - Domy drewniane rozebrane oraz w nieodwracalnym staniezniszczone lub przekształcone w latach 2005-2017; 3. - Wybudowane nowe domy wg wzornika będącego częścią MPZP; 4. - Adaptacje domów drewnianych zgodnie z zasadami wzornika; 5. - Granica strefy ochrony konserwatorskiej; 6. - granica zespołu urbanistycznego wpisanego do rejestru zabytków; 7. - Zmodernizowany i badany budynek przy ul. Wiktorii 5; (oprac. M. Tur, na podstawie inwentaryzacji

Fig. 2. Wooden housesin the main part of Bojary district. Designations: 1. - Existing wooden houses; 2. - Wooden houses demolished or in irreversible condition destroyed or transformed since 2005; 3. - New houses built according zoning plan; 4. - wooden houses modernized in accordance with the rules of zoning plan; 5. - Conservation protection zone border; 6 . - boundary of the urban complex included in the Register of objects of cultural heritage; 7. - Buildingtested for airtightness (by M. Tur)

\section{Stan zachowania zabudowy drewnianej}

Analizie zachowania drewnianej zabudowy poddałem obszar tzw. Serca Bojar, ograniczonego ulicami Chopina, Modlińską Piasta i Skorupską. Materiał porównawczy w postaci mapy zasadniczej (rys. 2.) pochodzi z lat 2005-2007, kiedy utworzone zostały karty ewidencyjne większości domów. Pomimo objęcia terenu rygorystycznymi zapisami w Miejscowym Planie Zagospodarowania Przestrzennego, funkcjonowania programu rewitalizacji i ochrony konserwator- 
skiej, z 95 domów drewnianych 25 zostało zniszczonych lub rozebranych. Wśród inwestycji z ostatniej dekady, przeprowadzono trzy rewaloryzacje domów drewnianych (wśród nich obiekt przy ul. Wiktorii 5), postawiono zgodnie $\mathrm{z}$ wzornikiem trzy nowe budynki murowane $\mathrm{w}$ miejsce rozebranych domów (tab. 1.).

Tabela1. Struktura zabudowy Serca Bojar(oprac. M. Tur na podstawie inwentaryzacji)

Table 1. District housingstructure in the Heart of Bojary (by M. Tur)

\begin{tabular}{|l|c|c|}
\hline Rodzaj budynków & Liczba (szt.) & \% \\
\hline Budynki ogółem* & $\mathbf{1 2 1}$ & $\mathbf{1 0 0}$ \\
\hline Domy drewniane zachowane do 2017 r. & $\mathbf{7 0}$ & $\mathbf{5 8}$ \\
\hline $\begin{array}{l}\text { Domy zburzone lub nieodwracalnie uszkodzone w latach 2005- } \\
2017\end{array}$ & $\mathbf{2 5}$ & $\mathbf{2 0}$ \\
\hline Nowe domy postawione zgodnie z wzornikiem & $\mathbf{4 ( 7 )}$ & $\mathbf{3 ( 6 )}$ \\
\hline Modernizacje zgodnie z wzornikiem & $\mathbf{3}$ & $\mathbf{2}$ \\
\hline
\end{tabular}

* bez uwzględnienia budynków gospodarczych i innychpomocniczych

Nowym rozwiązaniem jest prowadzona przez spółdzielnię mieszkaniową inwestycja na pustych działkach przy ul. Wylotnej. Budowany jest tam wielorodzinny zespół mieszkaniowy w formie kilku domów uwzględniających wytyczne wzornika.Pozostałe domy drewniane w liczbie 70 , są w różnym stanie technicznym i prezentują obraz odpowiadający możliwościom finansowym i gustom ich mieszkańców - od pilnie wymagających robót ratunkowych domów w stanie oryginalnym, po obłożone szalówką PCV i taką samą stolarką. W większości wymagają przeprowadzenia gruntownych robót remontowych konstrukcji (wzmocnienie fundamentów, wymiana podwalin, remont więźby dachowej) i termomodernizacji (wykonanie całościowej osłony termicznej, w tym wymiana posadzek na gruncie w miejsce podłóg na legarach). W całościowym obrazie dzielnicy nie da się nie zauważyć trafności stwierdzeń autorów opracowań, mówiące o dysharmonii i utracie autentyzmu.

\section{Analiza bilansu energetycznego domów drewnianych}

Analiza energetyczna wraz z optymalizacją usprawnień jest jedną z podstawowych składowych wielu funkcjonujących programów rewitalizacji ${ }^{14}$. Program rewitalizacji Bojar powinien ujmować problematykę szczelności powietrznej, która w swojej wadze równa jest problemowi docieplenia ścian w wielkoprzemysłowym budownictwie wielorodzinnym. Dowodzą temu badania przeprowadzone w 2017 r. zgodnie z normą PN-EN 13829:2002. Badaniu poddano zrewaloryzowany budynek przy ul. Wiktorii 5 - zaadaptowany na funkcję muze-

${ }^{14}$ Ostańska A.: Podstawy metodologii tworzenia programów rewitalizacji dużych osiedli mieszkaniowych wzniesionych w technologii uprzemysłowionej na przykładzie osiedla im. St. Moniuszki w Lublinie, Wydawnictwa Uczelniane, Lublin 2009, s. 16-26. 
alną dom drewniany oraz dwa domy położone w podmiejskich wsiach, zbudowane w latach 40. XX w., odpowiadające konstrukcją domom bojarskim i zachowane $\mathrm{w}$ stanie oryginalnym i nieprzerwanie użytkowane. Badanie wykazało we wszystkich obiektach wielokrotne przekroczenie zalecanego $\mathrm{w} \mathrm{WT}^{15}$ pozio$\mathrm{mu}$ szczelności, równego $\mathrm{n}<3 / \mathrm{h}$ oraz stwierdzono miejsca nieszczelności przez badanie wzrokowe przepływu strugi dymu. W obu domach w stanie pierwotnym stwierdzono wysoki przepływ powietrza przez skrzynkową stolarkę okienną oraz nieciągłości obudowy spowodowane zniszczeniem drewna w różnych miejscach budynku. Nie stwierdzono nieszczelności przez nieuszkodzone oryginalne i poprawnie wykonane przegrody zewnętrzne w tym połączenia dyli ścian wieńcowych uszczelnione mchem (uszczelnienie to wykazało skuteczność po 50. latach). W budynku Galerii, przy ul. Wiktorii 5 na Bojarach, zbadana szczelność na poziomie $n=8,1 / \mathrm{h}$. Niekontrolowany przepływ powietrza stwierdzono na całej powierzchni osłony termicznej - w przebiciach technicznych przez wewnętrzną warstwę płyt g.-k. (gniazda elektryczne, styk płyt g.-k. z ościeżnicami, styk podłóg drewnianych na legarach i ścian zewnętrznych). W wyniku analizy dokumentacji stwierdzono nieciągłość warstw membran paroszczelnych na wszystkich powierzchniach przegród zewnętrznych i podłóg na gruncie. W zewnętrznej warstwie obudowy nieszczelności występowały na całym styku podwaliny z cokołem murowanym, połączeniach stolarki. Membrana paroszczelna nie posiadała ciągłości na styku ścian zewnętrznych i połaci dachu [13-14].

Przeprowadzone obliczenia bilansu energetycznego ${ }^{16}$ dla budynku przy ul. Wiktorii 5 pokazują jak istotna okazuje się szczelność powietrzna dla gospodarki cieplnej budynków drewnianych. Jednocześnie wykonanie szczelnej osłony budynku wiąże się ze stosunkowo prostym zabiegiem sklejania membran paroszczelnych oraz stosowaniem specjalnych taśm do montażu stolarki. Świadomość tego, że domy drewniane są „dziurawe” wydaje się powszechna, jednak zadziwia brak podejmowanych środków zaradczych, w tym weryfikacji wykonania robót budowlanych badaniami szczelności. Budynek przy ul. Wiktorii 5 wyposażony został $\mathrm{w}$ wydajny system wentylacji naturalnej, co w połączeniu $\mathrm{z}$ nieszczelnościami $\mathrm{w}$ obudowie może prowadzić wg obliczeń do $65 \%$ udziału w ogólnych stratach ciepła w budynku tylko na ogrzewanie napływającego zimnego powietrza. Wyposażenie budynku w system wentylacji mechanicznej z odzyskiem ciepła i automatyczną regulacją przepływu pozwoliłby na osiągnięcie wskaźnika EA na poziomie $66 \mathrm{kWh} / \mathrm{m}^{2}$ a (spadek zapotrzebowania na energię na ogrzewanie o 63\%). Wykonanie szczelnej membrany pozwoliłoby by na redukcję emisji równoważnej o 15,3\%, przy czym emisja $\mathrm{CO}_{2}$ zmniejszyła by się o $1054 \mathrm{~kg} / \mathrm{rok}$ (tab. 2.) [15].

\footnotetext{
${ }^{15}$ Rozporządzenie Ministra Infrastruktury z dnia 12 kwietnia 2002 r. w sprawie warunków technicznych, jakim powinny odpowiadać budynki i ich usytuowanie.

${ }^{16}$ Rozporządzenie Ministra Infrastruktury i Rozwoju z dnia 27 lutego 2015 r. w sprawie metodologii wyznaczania charakterystyki energetycznej budynku lub części budynku oraz świadectw charakterystyki energetycznej.
} 
Tabela 2. Wpływ szczelności powietrznej domów drewnianych na bilans energetyczny (oprac. M. Tur na podstawie przeprowadzonych badań i obliczeń w programie Audytor OZC)

Table 2. The influence of airtightness of wooden houses on the building energy balance (by M. Tur based on survey and software calculation)

\begin{tabular}{|l|c|c|c|c|c|}
\hline Budynek & $\begin{array}{l}\text { Wskaźnik } \\
\text { EA w stanie } \\
\text { istniejącym }\end{array}$ & $\begin{array}{l}\text { Szczelność } \\
\text { powietrzna } \\
\text { n50 w stanie } \\
\text { istniejącym } \\
{[\mathbf{1 / h}]}\end{array}$ & $\begin{array}{l}\text { Udział w stra- } \\
\text { tach energii z } \\
\text { powodu nie- } \\
\text { szczelności } \\
\text { [\%] }\end{array}$ & $\begin{array}{l}\text { Wskaźnik } \\
\text { EA przy } \\
\text { n50=3/h } \\
\text { wymaganej } \\
\text { w WT } \\
{[\mathbf{1 / h}]}\end{array}$ & $\begin{array}{c}\text { Zmniejszenie } \\
\text { zapotrzebowa- } \\
\text { nia na energię } \\
\text { przy szczelno- } \\
\text { ści n50=3/h } \\
\text { [\%] }\end{array}$ \\
\hline $\begin{array}{l}\text { Wiktorii 5 } \\
\text { przed mo- } \\
\text { dernizacją }\end{array}$ & 249 & $16^{*}$ & 21 & 184 & 26 \\
\hline $\begin{array}{l}\text { Wiktorii 5 } \\
\text { po moderni- } \\
\text { zacji }\end{array}$ & 178 & 8,1 & 39 & 152 & 15 \\
\hline Wiktorii 9 & 253 & $16^{*}$ & 25 & 185,8 & 22 \\
\hline Gliniana 6/2 & 223 & $16^{*}$ & 23 & 167,6 & 25 \\
\hline Ciumicze 8 & 389 & 32,4 & 32 & 264,6 & 30 \\
\hline $\begin{array}{l}\text { Bielewicze } \\
\text { 43 }\end{array}$ & 311 & $16^{*}$ & 15 & 257,3 & 14 \\
\hline
\end{tabular}

* przyjęto szczelność zmierzoną w analogicznym budynku Bielewicze 43

Wyposażenie budynku dodatkowo $\mathrm{w}$ system wentylacji mechanicznej z odzyskiem ciepła pozwoliłoby na zmniejszenia emisji odpowiednio o 39\% i $2726 \mathrm{~kg} / \mathrm{rok}$. Nabiera to szczególnego znaczenia w przypadku określenia dzielnicy jako ,zielonej enklawy”. Równie istotnym elementem poprawy warunków użytkowych jak efektywność energetyczna i zanieczyszczenie środowiska jest uzyskanie odpowiedniego komfortu cieplnego. Szczelność powietrzna bezpośrednio wpływa na ruch powietrza we wnętrzach (przeciągi), temperaturę powierzchni - podstawowe parametry do określania komfortu cieplnego zgodnie z normą PN-EN 7730.

W kosztach robót konserwatorskich pozwalających na zachowanie drewnianej konstrukcji - substancji historycznej będącej autentyczną częścią dziedzictwa miasta, powinno partycypować całe społeczeństwo. Składanie ciężaru finansowego na barki inwestorów prywatnych będzie prowadzić do kontynuacji obecnego stanu rzeczy, czyli stopniowej wymiany drewnianej konstrukcji wieńcowej na oszalowane domy murowane. Udział partycypacji powinien obejmować refundację kosztów przynajmniej remontu posadowienia oraz wymianę i zabezpieczenie elementów ścian wieńcowych. W przypadku usprawnień termomodernizacyjnych użyteczne jest obowiązujące rozporządzenie w sprawie audytu energetycznego, umożliwiające obliczenie prostego okresu zwrotu kosztów inwestycji z oszczędności kosztów ogrzewania. Mając do czynienia z powtarzalnym typem budynków i takimi samymi problemami, program rewitalizacji powinien zawierać katalog gotowych rozwiązań technicznych usprawnień 
termomodernizacyjnych, jak również zabiegów konserwatorskich z kalkulacją ich kosztów. Do standardowych usprawnień będą należeć: wymiana podłóg na legarach na izolowane posadzki na gruncie; wymiana szalówki zewnętrznej z wykonaniem docieplenia wełną mineralną; docieplenie połaci dachowych połączone $\mathrm{z}$ usunięciem polep i zasypek stropów i wykonaniem napraw (wzmocnień) konstrukcji dachu; wymiana lub remont stolarki okiennej i jej montaż z użyciem taśm uszczelniających; dokładne wykonanie membran warstw wewnętrznych (sklejenie arkuszy folii paroizolacyjnej); wymiana źródła ciepła na efektywne energetycznie jak np. hybrydowe pompy ciepła (powietrze/gaz ziemny). W obiektach użyteczności publicznej do spełnienia wymagań określonych w WT, niezbędne jest stosowanie wentylacji mechanicznej z odzyskiem ciepła.

\section{Wnioski}

Stan zachowania drewnianego domu w zadziwiający sposób połączony jest z witalnością mieszkańców. Problemy mieszkańców znajdują wyraźne odzwierciedlenie w stanie technicznym domu i w przeciwieństwie do budynku murowanego prowadzą do szybkiej i często nieodwracalnej degradacji technicznej. Stąd też wynika szczególna potrzeba przeprowadzenia w dzielnicy Bojary działań rewitalizacyjnych obejmujących działania wszystkich niezbędnych zespołów programowych. Podjęte działania w zakresie ochrony krajobrazu i przemian społecznych przyniosły efekty - dzielnica nie została zakwalifikowana jako obszar zdegradowany. Niestety nie można stwierdzić, że w pełni zachowana została wartość zabytkowa. Ujęcie analizy efektywności energetycznej z wyszczególnieniem problemu szczelności powietrznej wraz z prezentacją technicznych środków zaradczych i wsparciem finansowym $w$ realizowanym programie rewitalizacyjnym z pewnością podwyższyłoby efektywność programu na płaszczyźnie ekonomicznej (zmniejszenie kosztów ogrzewania budynków) i poprawy warunków bytowych prze zmniejszenie zanieczyszczenia powietrza (mniejsza emisja zanieczyszczeń). Upowszechnienie narzędzi technicznych poprawy efektywności energetycznej budynków drewnianych pozwoliłoby większemu gronu inwestorów zdecydować o zachowaniu posiadanej części naszego wspólnego dziedzictwa.

W przygotowywanym obecnie programie rewitalizacji miasta Białegostoku dzielnica nie znalazła się w grupie obszarów wytypowanych do działań rewitalizacyjnych ze względu na zanik problemów społecznych będących podstawą kwalifikacji - lokatorzy mieszkań komunalnych zostali wysiedleni. Podobny w skutkach proces nieprzerwanie trwa w przypadku drewnianych domów, zastępowanych murowanymi o tradycyjnej skali, formie i drewnianej okładzinie zewnętrznej. Utrzymane zostają w ten sposób historyczne uwarunkowania urbanistyczne, jednak zabraknie tak istotnego dla charakteru dzielnicy autentyzmu. 


\section{Literatura}

[1] Popławski T.: Przestrzeń współczesnego miasta Białegostoku na tle historycznych podziałów, Białostocczyzna 2/96, Białystok 1996 r., s. 11-12.

[2] Korolczuk D., Maroszek J., Popławski T.:Wartości przestrzeni i środowiska kulturowego dzielnicy Bojary, Białostocczyzna 3/94, Białystok 1994 r., s. 72.

[3] Turecki A.: „Plan duChateau et de la ville de Białystok avecsesenvirons”, Zeszyty Naukowe Politechniki Białostockiej 1996 r.

[4] Dobroński A.: Białystok, historia miasta, Urząd Miasta Białegostoku, Białystok 2001.

[5] Dolistowska M.: W poszukiwaniu... s.151-155.

[6] Wicher S.: „Drewniany” modernizm w Białymstoku na przykładzie domu przy ul. Słonimskiej 31, Biuletyn Konserwatorski Województwa Podlaskiego, Białystok 2008.

[7] Dokumentacja fotograficzna dzielnicy Bojary, P.P. P.K.Z./O Białystok, lata 80. XX w. archiwum Narodowego Instytutu Dziedzictwa OT w Białymstoku.

[8] Tur M.: Sposoby kształtowania komfortu cieplnego w drewnianym budownictwie mieszkaniowym Białegostoku z początku XX w., Wybrane kierunki badań ergonomicznych w 2016 r., Wydawnictwo Polskiego Towarzystwa Ergonomicznego, Wrocław 2016.

[9] Szewczyk J.: Piec i komin w tradycyjnym budownictwie ludowym Podlasia, Oficyna Wydawnicza Politechniki Białostockiej, $2011 \mathrm{r}$.

[10] Dąbrowska-Milewska G.: Problemy ochrony wartości kulturowych w praktyce planowania przestrzennego na przykładzie dzielnicy Bojary w Białymstoku, Zeszyty naukowe Politechniki Białostockiej 1996 r.

[11] Polityka mieszkaniowa Białegostoku”, UM w Białymstoku, Białystok, 1997 r.

[12] Oleksicki A., Tomecka B., Stanisławska A., Lewkowicz P.: Opracowanie konserwatrosko-urbanistyczne dla dzielnicy Bojary wykonane na zlecenie Prezydenta Miasta Białegostoku, PPKZ S.A. O/Białystok, 2006.

[13] Ostańska A.: Podstawy metodologii tworzenia programów rewitalizacji dużych osiedli mieszkaniowych wzniesionych w technologii uprzemysłowionej na przykładzie osiedla im. St. Moniuszki w Lublinie, Wydawnictwa Uczelniane, Lublin 2009, s. 16-26.

[14] Rozporządzenie Ministra Infrastruktury z dnia 12 kwietnia 2002 r. w sprawie warunków technicznych, jakim powinny odpowiadać budynki i ich usytuowanie.

[15] Rozporządzenie Ministra Infrastruktury i Rozwoju z dnia 27 lutego 2015 r. w sprawie metodologii wyznaczania charakterystyki energetycznej budynku lub części budynku oraz świadectw charakterystyki energetycznej. 


\section{ANALYSIS OF THE ENERGY EFFICIENCY OF BUILDINGS IN THE BOJARY HISTORICAL DISTRICT IN BIAEYSTOK, AS A PART OF THE REVITALIZATION PROGRAM}

\section{S u m m a r y}

Adaptation of historical buildings to modern requirements of thermal comfort with a low cost of maintenance is one of the main obstacles in the process of revitalization of historic districts. Lack of specific technical modernization solutions in the revitalization program can lead to common interventions that results in the loss of attributes being a part of cultural heritage and finally to the failure of the revitalization program. Inner-city district Bojary with its wooden houses is an example of the disappearing material and cultural heritage of the city. Over the past several decades, the district has experienced a number of revitalization efforts with finally enaction of a rigorous zoning plan. Despite this, only $58 \%$ of wooden houses have preserved to this day. The paper presents the historical outline of the district, the current state of preservation and the revitalization efforts undertaken so far. An analysis of the energy balance of wooden houses has been described, taking into account the results of conducted airtightness tests. The study was based on field research, survey and computational methods. The result of the research is the indication of energy efficiency issue of historical buildings as one of the key elements of the revitalization program.

Keywords: Wooden houses, airthightness, energy efficiency, conservation of historical buildings

Przestano do redakcji: 09.06.2017 $r$.

Przyjęto do druku: 01.09.2017 r. 